\title{
Camouflaging of seeds treated with pesticides mitigates the mortality of wild birds in wheat and rice crops
}

\author{
Alexandre de Almeida ${ }^{1}$; Hilton Thadeu Zarate do Couto ${ }^{2 *}$; Álvaro Fernando de Almeida ${ }^{2}$ \\ ${ }^{1} U F B A / I B$ - Depto. de Zoologia - Lab. de Vertebrados Terrestres, R. Barão de Geremoabo, s/n. - 40170-115 - \\ Salvador, $B A-$ Brasil. \\ ${ }^{2}$ USP/ESALQ - Depto. de Ciências Florestais, C.P. 9 - 13400-970 - Piracicaba, SP - Brasil. \\ *Corresponding author < btzcouto@esalq.usp.br>
}

\begin{abstract}
Seeds used to plant wheat, corn and rice crops in Brazil are treated with the insecticide carbofuran associated with the dye rhodamine $\mathrm{B}$, attracting granivorous birds and causing mortality during sowing. The objective of this study was to evaluate if using camouflaged seeds can minimize mortality caused by the ingestion of seeds with carbofuran. Alternatives for reducing mortality, such as using carbofuran without rhodamine B or replacing carbofuran by carbosulfan, were compared. Three experiments were carried out in regions of known bird mortality in the states of Paraná and São Paulo, Brazil, using conventional sowing over plowed soil in the traditional planting system, $15,896 \mathrm{~kg}$ of seeds in 111.46 ha. Bird carcasses were collected and dissected to unveil which poisoned seed treatments had caused birds' deaths. The mortality mounted to 296 birds of 11 species. Eared doves were the most numerous casualties (263). There was significant correlation between mortality and number of consumed seeds. The consumption of camouflaged seeds was lower than that of commercial seeds treated with rhodamine B. The mortality caused by seeds with both rhodamine $B$ and carbofuran was higher than mortality caused by seeds camouflaged only with carbofuran. The replacement of carbofuran with carbosulfan also seemingly reduced mortality, but carbosulfan mortality might have been underestimated as a result of the apparent movement of affected birds after exposure. Seeds treated with carbofuran and rhodamine B and without any dye, were attractive. Because legal requirement for seeds treated with pesticides to be differentiated by dying, the substitution of rhodamine B by camouflaging must be encouraged.
\end{abstract}

Key words: Zenaida auriculata, carbofuran, rhodamine B, carbosulfan, gustatory repellents, environmental impact

\section{Camuflagem de sementes tratadas com pesticidas mitiga a mortalidade de aves silvestres em plantações de trigo e arroz}

\begin{abstract}
RESUMO: Plantações de trigo, milho e arroz no Brasil utilizam sementes tratadas com o inseticida carbofuran, associado ao corante rodamina $\mathrm{B}$, que é atrativo às aves granívoras, causando notável mortalidade durante o plantio. O objetivo deste estudo foi avaliar se sementes camufladas minimizam a mortalidade de aves, causada pela ingestão de sementes tratadas com carbofuran. Possíveis alternativas para redução da mortalidade como carbofuran sem a rodamina B e o carbusulfan, foram testadas comparativamente. Realizaram-se três experimentos em regiões de expressiva mortalidade de aves no Paraná e São Paulo. Semeaduras foram convencionais sobre solo arado no sistema de plantio tradicional, utilizando $15.896 \mathrm{~kg}$ de sementes em 111,46 ha. Carcaças de aves foram coletadas e dissecadas, revelando quais tratamentos de sementes envenenadas causaram mortes. A mortalidade foi de 296 aves de 11 espécies. Pombas avoantes foram as vitimas mais numerosas com 263 mortes. Houve correlação significativa entre mortalidade e quantidade de sementes consumidas. O consumo de sementes camufladas e com carbofuran foi menor em relação ao de sementes com rodamina B e com carbosulfan. A mortalidade causada por sementes com rodamina $\mathrm{B}$ e carbofuran foi maior em relação à causada por sementes camufladas e com carbofuran, que foi igual à causada por sementes com rodamina B e carbosulfan, cujo inventário foi subestimado. Sementes tratadas com carbofuran, com e sem rodamina B, foram atrativas. Como sementes tratadas com agrotóxicos devem por lei receber coloração diferenciada para evitar acidentes com humanos, camuflagem de sementes deve ser encorajada substituindo a rodamina B.

Palavras-chave: Zenaida auriculata, carbofuran, rodamina B, carbosulfan, repelentes gustativos, impacto ambiental
\end{abstract}

\section{Introduction}

Seeds treated with carbofuran, carbosulfan and pyrethroids and which are not properly buried at sowing represent a food source for granivorous birds, causing not only mortality of flocks by deliberate ingestion, but also death of predators and scavengers by secondary poisoning. According to the Brazilian Federal Decree 4074, January 4, 2002, agrochemical defensives must be added to the seeds in association with dyes, to reduce the risk of human ingestion and poisoning. Rhodamine B dye is frequently used with that purpose, and its purple-reddish 
hue contrast with soil is striking to wild birds (Hartley et al., 2000; Schmidt et al., 2004).

High mortality rates of carnivorous and granivorous birds caused by pesticides of the carbamate group (Eisler, 1985; Agriculture Canada, 1993; Mineau 1993; Mineau et al., 1999; Mineau, 2005), as well as attempts to repel birds through acoustic, tactile, visual and/or gustative methods (Hawthorne, 1987; Dolbeer, 1999; Avery, 2002; Tobin, 2002) have all been documented. Research has evolved trying to find chemical repellents and or aversive colors for reducing the damage on production and decreasing the poisoning risks for the wild fauna (Tobin, 2002; Avery, 2002).

The objective of this study was evaluating the role of camouflaged seeds on the minimization of mortality of wild birds caused by the ingestion of commercial seeds treated with pesticides and rhodamine B. Cryptic behavior and camouflaging are quite successful evolutionary adaptations, which decrease chances of detecting a species, whose color or shape are similar to common aspects in the environment they live in (Zug et al., 2001; Merilaita, 2003).

Alternative strategies for reducing mortality, like the use of carbofuran without rhodamine B and the use of carbosulfan were also tested. Carbofuran without rhodamine B gives a 'beige' hue to seeds and could make them less attractive to birds, representing economic savings at planting. Carbosulfan, a carbamate with insecticidal and nematicidal properties and with a lethal dose circa 20 times weaker than carbofuran, could act as a chemical repellent if the birds were able to link the poisoning symptoms to the food, halting the consumption before dying.

\section{Material and Methods}

Experiments in rice and wheat plantations were performed in regions where mortality of birds resulting from the ingestion of seeds treated with pesticides, was reported by farmers. Experiments were performed at sowing, when numerous flocks of birds were present.

The powdered, brown-colored dye used to camouflage the seeds was obtained through mixing red, black, blue, brown and yellow powdered dyes, so a hue similar to local soil samples was reached.

The whole camouflaging process was performed in the same machine used in the treatment of commercial seeds with carbofuran. For treating the seeds, carbofuran was used (2,3-dihydro-2,2-dimethyl-7-benzofuranyl methylcarbamate), in a concentrated suspension of 350 $\mathrm{g} \mathrm{L}^{-1}$. The dosage of carbofuran used for wheat or rice seeds was $2 \mathrm{~L}$ for $100 \mathrm{~kg}$. Carbofuran's toxicity (human $\mathrm{LD}_{50}=8-12 \mathrm{mg} \mathrm{kg}^{-1}$ ) was high enough to kill in situ small $\left(\mathrm{H}^{\prime} 40 \mathrm{~g}\right)$ and medium-sized birds $(\mathrm{H}$ "120 g) ingesting treated seeds.

Conventional, dry land sowing by a tractor-mounted gravity seed drill over plowed soil in the traditional planting system was used. Treatments were laid in parcels no further than $700 \mathrm{~m}$ from each other.
Two searches for dead birds were made per day (Mineau, 2005) in each parcel. Search groups of two to four people walking $\left(\mathrm{H}^{\prime} 3 \mathrm{~km} \mathrm{~h}^{-1}\right)$ or driving a pick-up truck $\left(\mathrm{H}^{\prime} 5 \mathrm{~km} \mathrm{~h}^{-1}\right)$ within and around the parcels. Bird carcasses were collected and identified. Contents of digestive tract of bird carcasses were collected separately as follows: i) crop and esophagus; ii) proventriculus; and iii) gizzard. Consumption of seeds from each treatment was evaluated.

The treatments 'rhodamine B' and 'powder dye camouflaging' have been investigated in three experiments. Their results were analyzed and summarized apart from the other treatments as well. In these statistical analyses, 19 days of experimental exposure were used as repeated samples. Birds able to ingest seeds from more than one treatment were excluded from the analysis.

Experiment 1 - The following treatments with wheat seeds were tested: i) red seeds treated with carbofuran and rhodamine B; ii) brown seeds camouflaged with powdered dye, treated with carbofuran. Four kg of powdered dye were used for every $100 \mathrm{~kg}$ of seeds previously treated with carbofuran. Tests were performed from 15 to 17 of May, 1981 and from 28 to 31 of May,

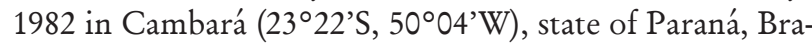
zil) as well as in Assis $\left(22^{\circ} 35^{\prime} \mathrm{S}, 50^{\circ} 22^{\prime} \mathrm{W}\right.$, state of São Paulo, Brazil) from 9 to 11 of September, 1981. The total experimental area consisted of $10 \mathrm{ha}$, divided into 1 ha parcels. Five ha were assigned to each treatment. Because of varying seed quality, in Cambará, four parcels received $87.5 \mathrm{~kg}$ of wheat seeds per ha and another four parcels received $150 \mathrm{~kg}$ of wheat seeds per ha. In Assis, $200 \mathrm{~kg}$ of wheat per ha were used. The amount of seeds in parcels and among treatments was balanced. A total of $1,350 \mathrm{~kg}$ of seeds was used. The rhodamine $\mathrm{B}$ formula is 9-(o-carboxyphenyl)-6-(diethylamino)-3h-xanthen-3ylidene)diethyl-ammoniu.

Experiment 2 - Treatments applied to the rice seeds were: i) red seeds treated with carbofuran and rhodamine B; ii) brown seeds, camouflaged with powdered dye and treated with carbofuran; iii) red seeds treated with carbosulfan and rhodamine B. For treating the seeds, powder carbosulfan, in a concentration of 350 $\mathrm{g} \mathrm{kg}^{-1}$, was used; the dosage was $3 \mathrm{~kg}$ powder per $100 \mathrm{~kg}$ of seeds. The carbosulfan formula is 2,3-dihydro-2,2-dimethyl-7-benzofuranyl((dibutylamino)thio)methyl carbamate. Carbosulfan toxicity for humans was $\mathrm{LD}_{50}=212$ $\mathrm{mg} \mathrm{kg}^{-1}$. Treatments were set on seven parcels of 0.26 ha, adding up to $5.46 \mathrm{ha} .100 \mathrm{~kg}$ of seeds per hectare. The amount of seeds in parcels and among treatments was balanced. The field experiment was set up in Assis, SP. In 01/25/1983.During a first phase that lasted four days, nine parcels were seeded; on the four-day second phase (02/08/1983), 12 parcels were seeded.

Experiment 3 - Treatments applied to wheat seeds were: i) red seeds treated with carbofuran and rhodamine B; ii) brown seeds, camouflaged with liquid dye, treated 
with carbofuran; iii) beige seeds, treated with carbofuran without rhodamine B; iv) brown seeds, camouflaged with powder dye, treated with carbofuran. The experiment was conducted in Maringá region, Floraí town (23⒉' $\left.52^{\circ} 22^{\prime} \mathrm{W}\right), \mathrm{PR}$, at São José Farm, from 6 to 10 of April, 1982. The total assay area was 96 ha, divided into four equal parcels of $24 \mathrm{ha}$, each one receiving $3,500 \mathrm{~kg}$ of seeds. The liquid dye used in the camouflaging was obtained by mixing red, blue, yellow, black and brown pigments in water, and then adding the slurry to the carbofuran syrup in proportions that allowed a proper camouflage to match the region's soil color.

Analysis - Numerical variations of dead birds and consumed seeds between treatments were checked through Kruskal-Wallis, and the association among the variables 'death' and 'ingested seeds' was evaluated using Spearman correlation analysis. Statistical procedure considered eight, seven and four days of experimental exposure as repeated samples, for experiments one, two and three, respectively.

\section{Results and Discussion}

Details about the 24 birds found intoxicated in Experiment 1 are given in Table 1. Table 2 brings the pro- portions of deaths and seed consumption for the two treatments. Camouflaged seeds were easily distinguished from those treated with rhodamine B in the bird's digestive tract based on different color and texture.

The digestive systems of burrowing owls and rufouscollared sparrows, found in the red-treatment parcels were empty, indicating they regurgitated the food. Next to a living roadside hawk, a regurgitation containing insects was found. A cloud of powder released by the seed drill next to the ground was observed during sowing, and it may have poisoned arthropods. Some birds died after ingesting a single seed, found either in the crop [ruddy ground doves $(n=2)$, eared dove $(n=1)]$; in the gizzard [ruddy ground doves $(\mathrm{n}=2)$ ]; or in the proventriculus [ruddy ground dove $(\mathrm{n}=1)$ ]. These observations prove that carbofuran, even in small amounts, is fatally toxic for small and medium-sized doves, i.e. eared doves $(\mathrm{H}$ ” $120 \mathrm{~g})$ and ruddy ground doves $(\mathrm{H}$ ” $40 \mathrm{~g})$.

Many clusters of feathers were found, indicating the action of carnivore scavengers and predators on the poisoned fauna. In some of these feathers spots, it was possible to distinguish the actions of carnivorous mammals through the identification of dental cuts on feather spines (calamus).

Table 1 - Quantitative list of 11 species of birds intoxicated by pesticides in the wheat and rice planting experiments 1, 2 and 3.

\begin{tabular}{llcccc}
\hline Scientific name & \multicolumn{1}{c}{ Popular name } & Exp.1 wheat & Exp.2 Rice & Exp.3 wheat & Ind. \\
\hline Zenaida auriculata & Eared dove & 4 & 195 & 64 & 263 \\
Columbina talpacoti & Ruddy ground dove & 13 &. &. & 13 \\
Speotyto cunicularia & Burrowing owl* & 3 &. & 4 & 7 \\
Gnorimopsar chopi & Chopi blackbird &. & 3 &. & 3 \\
Patagioenas sp. & Plumbeous pigeon &. &. & 2 & 2 \\
Rupornis magnirostris & Roadside hawk* & 2 &. &. & 2 \\
Leptotila rufaxilla & White-tipped dove & 1 &. &. & 1 \\
Zonotrichia capensis & Rufous-collared sparrow & 1 &. &. & 1 \\
Patagioenas picazuro & Picazuro pigeon &. &. & 1 & 1 \\
Falco sparverius & American kestrel* &. &. & 1 & 1 \\
Notbura maculosa & Spotted nothura &. &. & 1 & 1 \\
Nystalus chacuru & White-eared puffbird* &. &. & 1 & 1 \\
\hline Total of intoxicated victims & & 24 & 198 & 74 & 296 \\
\hline
\end{tabular}

Legend: Exp. - experiment; Ind. - the total number of individuals intoxicated for each bird species; asterisk (*) indicates carnivorous birds; absence of asterisk indicates granivorous-insectivorous species.

Table 2 - Mortality of birds and consumption of camouflaged and red seeds in the wheat planting experiment 1 . The percentages refer to the total mortality and seeds found; the averages and variances refer to the daily counts.

\begin{tabular}{lccccc}
\hline & \multicolumn{2}{c}{ Mortality } & & \multicolumn{2}{c}{ Seed } \\
\cline { 2 - 3 } \cline { 5 - 6 } & Camouflaged & Red & & Camouflaged & Red \\
\hline Total & 1 & 21 & & 1 & 62 \\
Percentage & 4.54 & 95.45 & & 1.58 & 98.41 \\
Average & 0.12 & 2.62 & & 0.12 & 7.75 \\
Variance & 0.12 & 6.83 & & 0.12 & 30.78 \\
\hline
\end{tabular}


The dissection of a roadside hawk's digestive tract revealed parts of eared dove and five red wheat seeds eaten by the dove, proving secondary intoxication of the hawk. Pesticides may be incorporated in several levels on the food chain, threatening survival, fitness and breeding of several species of fauna (Cox, 1996).

Bird mortality resulting from the camouflaged seed treatment was lower $(\mathrm{H}=5.6 ; p=0.01, \mathrm{df}=1)$, and the consumption of camouflaged seeds was also lower when compared to red seeds $(\mathrm{H}=5.83 ; p=0.01 ; \mathrm{df}=1)$ (Table 2). The Spearman coefficient showed a high correlation between the variable 'number of consumed seeds' and 'bird mortality' ( $\mathrm{r}=0.97 ; p<0.001 ; \mathrm{n}=16$ pairs). The correlation between mortality and seed consumption may be explained by the high toxicity of carbofuran and its rapid toxic action, seeing that a few ingested seeds may kill the bird. Thus, as a bird eats a few seeds and dies, the number of consumed seeds is directly proportional to the mortality, as expressed in the results of the correlation analysis between bird mortality and amount of ingested seeds Experiment 1. The difference in bird mortality and seed ingestion among treatments suggest that seed camouflage reduces the ability of birds locating seeds, avoiding consumption and consequent poisoning.

The proportion of deaths and seed consumption in each treatment are found in Tables 3 and 4. Birds affected by the carbosulfan were observed flying away with erratic movements in the presence of the search group. Such birds were, sometimes, able to run over 500 $\mathrm{m}$, which made it difficult to measure accurately the mortality caused by this pesticide. Regarding eared doves, a single carbofuran-treated seed in the crop was fatal, but birds killed by carbosulfan had at least six or seven seeds in their crop $(n=4)$.

Results of the Kruskal-Wallis analysis of mortality data revealed heterogeneity $(\mathrm{H}=6.79 ; p=0.03 ; \mathrm{df}=2)$.
According to a posteriori Student-Newman-Keuls test (Table 5), no differences between camouflaged and carbosulfan-treated red seeds were detected, but there was heterogeneity between camouflaged and carbofurantreated red seeds $(p=0.04)$, and between carbofurantreated seeds and carbosulfan-treated seeds $(p=0.01)$. The test indicated a higher mortality only in the treatment with carbofuran and rhodamine $B$ at a 5\%-significance level (Table 5), that is, the camouflaged treatment reduced bird mortality. The variation on the average of ingested seeds between treatments was not significant; neither there has been a significant correlation between bird mortality and consumed seeds.

In Experiment 3, the total death toll was 74 (Table 1). The distribution of deaths in relation to treatments is presented in Table 6 and the proportions of consumed seeds in Table 7. Eighteen feather agglomerates indicated the action of predators and scavengers removing carcasses in the following proportions: 14 in the beige treatment, one in the red treatment, three in the liquid brown treatment and none in the powder brown treatment. Since only heaped feathers were found, these observations were neither included on Table 6 nor on the variance analysis. One picazuro pigeon and one eared dove that ingested seeds from more than one treatment were excluded from the analysis. Three of the four powder camouflaged seeds were found in a picazuro pigeon, which had also eaten 15 beige-colored seeds.

Still on Experiment 3, there was marginal differences in mortality between the 'beige' and the 'powder brown' treatments $(\mathrm{H}=3 ; p=0.08 ; \mathrm{df}=1)$, and in relation to the 'carbofuran with rhodamine $\mathrm{B}$ ' and the 'powder brown' $(\mathrm{H}=3.03 ; p=0.08 ; \mathrm{df}=1)$. No differences between treatments regarding the quantity of consumed seeds according to the variance analysis were detected, but the Spearman correlation between mortality and consumed seeds was significant $(\mathrm{r}=0.95 ; p<0.001$; $\mathrm{n}$

Table 3 - Mortality of birds in the rice planting experiment 2. The percentages refer to the total mortality; the averages and variances refer to the daily counts

\begin{tabular}{lccc}
\hline & $\begin{array}{c}\text { Carbofuran and } \\
\text { rhodamine B }\end{array}$ & $\begin{array}{c}\text { Carbofuran and } \\
\text { camouflaging }\end{array}$ & $\begin{array}{c}\text { Carbosulfan and } \\
\text { rhodamine B }\end{array}$ \\
\hline Total & 109 & 49 & 40 \\
Percentage & 55.05 & 24.74 & 20.20 \\
Average & 13.625 & 6.12 & 5 \\
Variance & 50.26 & 44.69 & 30.57 \\
\hline
\end{tabular}

Table 4 - Consumption of camouflaged and red seeds in the rice planting experiment 2 . The percentages refer to the consumed seeds; the averages and variances refer to the daily counts.

\begin{tabular}{lccc}
\hline & $\begin{array}{c}\text { Carbofuran and } \\
\text { rhodamine B }\end{array}$ & $\begin{array}{c}\text { Carbofuran and } \\
\text { camouflaging }\end{array}$ & $\begin{array}{c}\text { Carbosulfan and } \\
\text { rhodamine B }\end{array}$ \\
\hline Total & 156 & 172 & 76 \\
Percentage & 38.61 & 42.57 & 18.81 \\
Average & 39 & 43 & 19 \\
Variance & 604 & 1830 & 376.66 \\
\hline
\end{tabular}


$=16$ pairs). Despite the marginally significant results between the treatments, the numerical discrepancies observed in Tables 6 and 7 elicit infer that the beige color was attractive to birds and that the camouflaged treatment with powder dye was efficient for minimizing bird mortality and seed consumption when treatments with carbofuran are compared, either in the presence or absence of rhodamine B.

The digestive systems of burrowing owl, spotted nothura, white-eared puffbird and american kestrel insectivorous birds were empty. Probably these specimen's deaths came from the poisonous cloud of dust, similar to Experiment 1, where the birds also regurgitated. The ability that certain birds have to regurgitate poisoned seeds may be a factor that decreases mortality (Pascual et al., 1999).

The liquid dye did not fully cover many of the seeds, a fact which, in addition to the lack of superficial ruggedness from the powder, may have influenced the results. Color and a rugged surface originated from the

Table 5 - Student-Newman-Keuls a posteriori test for multiple average comparisons, applied to the mortality of birds in rice planting experiment 2 .

\begin{tabular}{|c|c|c|c|c|}
\hline \multicolumn{3}{|c|}{ Treatment } & \multirow{2}{*}{$\frac{Q}{3.27}$} & \multirow{2}{*}{$\begin{array}{c}p \\
<0.05\end{array}$} \\
\hline $\begin{array}{l}\text { Carbofuran } \\
\text { Rhodamine B }\end{array}$ & . & $\begin{array}{l}\text { Carbofuran } \\
\text { Camouflaging }\end{array}$ & & \\
\hline $\begin{array}{l}\text { Carbofuran } \\
\text { Rhodamine B }\end{array}$ & - & $\begin{array}{l}\text { Carbosulfan } \\
\text { Rhodamine B }\end{array}$ & 3.77 & $<0.05$ \\
\hline $\begin{array}{l}\text { Carbosulfan } \\
\text { Rhodamine B }\end{array}$ & & $\begin{array}{l}\text { Carbofuram } \\
\text { Camouflaging }\end{array}$ & 0.49 & $>0.05$ \\
\hline
\end{tabular}

Legend: Q - squares; $p$ - probability powder help camouflaged seeds blend with the soil, minimizing defined contrasts and contours (Frankel et al., 2004; Merilaita and Lind, 2005).

The consolidation of results from Experiments 1, 2 and 3 , is found on Table 8 . There was a significant correlation between mortality and consumed seeds $(\mathrm{r}=$ $0.53 ; p<0.001 ; \mathrm{n}=38$ pairs); mortality of smaller birds was caused by camouflaged seeds $(\mathrm{H}=6.91 ; p=0.008$; $\mathrm{df}=1)$ and lesser ingestion of these seeds $(\mathrm{H}=4.92 ; p$ $=0.02 ; \mathrm{df}=1)$.

The brown color and the powder dye, rich in iron oxide, decrease the spectral reflectance (Hartley et al., 2000; Demattê et al., 2003; Espig et al., 2005; Almeida, 2006) of seeds in the wave lengths visible by the Passeriforms and Columbidae (Hart, 2001), turning them similar to the soil. In addition, powder camouflaged coating yields an opaque surface and, for this reason, shines less than seeds treated with rhodamine, being less conspicuous (Schmidt et al., 2004; Cuthill et al., 2005).

Finally, another possible reason for the lower camouflaged seed consumption, may be the absence of search image (Begon et al., 2006) to brown seeds with higher energy consumption for locating seeds in colors similar to the soil, according to optimal foraging theorem (Avery, 2002). However, the ingestion of small grits to help crush foods is a common aspect in the behavior of several bird Families (Sick, 1997). So, it is possible that brown-dyed seeds are less removed due to a set of factors linked to the camouflaging phenomenon, like background match, avoiding well defined contours and color contrasts (Merilaita 2003, Frankel et al., 2004; Schmidt et al., 2004), and not only because of the aversion to the

Table 6 - Bird mortality among the beige, red, camouflaged with liquid and camouflaged with powder treatments in wheat planting experiment 3 . The percentages refer to the total mortality; the averages and variances refer to the daily counts.

\begin{tabular}{lrrrc}
\hline Treatment & Beige & Red & L. Brown & P. Brown \\
\hline Total & 29 & 16 & 4 & 0 \\
Percentage & 59.18 & 32.65 & 8.16 & . \\
Average & 7.25 & 4 & 1 & . \\
Variance & 62.25 & 29.33 & 4 & . \\
\hline
\end{tabular}

Legend: Beige - carbofuran without rhodamine B; Red - carbofuran with rhodamine B; L. Brown - carbofuran-treated seed camouflaged with brown liquid dye; P. Brown - carbofuran-treated seed camouflaged with brown powder dye.

Table 7 - Seed consumption among the beige, red, camouflaged with liquid and camouflaged with powder treatments in wheat planting experiment 3 . The percentages refer to the consumed seeds; the averages and variances refer to the daily counts.

\begin{tabular}{lrrrc}
\hline Treatment & Beige & Red & L. Brown & P. Brown \\
\hline Total & 268 & 68 & 47 & 4 \\
Percentage & 69.25 & 17.57 & 12.14 & 1.03 \\
Average & 111 & 52.75 & 11.75 & 1 \\
Variance & 15322 & 3760.91 & 552.25 & 4 \\
\hline
\end{tabular}

Legend: Beige - carbofuran without rhodamine B; Red - carbofuran with rhodamine B; Liquid Brown - camouflaging with brown liquid dye; Powder Brown - camouflaging with brown powder dye. 
Table 8 - Mortality of birds and consumption of camouflaged and red seeds in the planting experiments 1, 2 and 3 . The percentages refer to the total mortality and seeds found; the averages and variances refer to the daily counts.

\begin{tabular}{lccccc}
\hline \multirow{2}{*}{ Treatment } & \multicolumn{2}{c}{ Deaths } & & \multicolumn{2}{c}{ Seeds } \\
\cline { 2 - 3 } \cline { 5 - 6 } & $\begin{array}{c}\text { Camouflaged } \\
\text { with carbofuran }\end{array}$ & $\begin{array}{c}\text { Rhodamine B } \\
\text { with carbofuran }\end{array}$ & & $\begin{array}{c}\text { Camouflaged } \\
\text { with carbofuran }\end{array}$ & $\begin{array}{c}\text { Rhodamine B } \\
\text { with carbofuran }\end{array}$ \\
\hline Total & 50 & 146 & & 177 & 429 \\
Percentage & 25.5 & 74.5 & & 29.2 & 70.7 \\
Average & 2.63 & 7.68 & & 11.8 & 28.6 \\
Variance & 28.8 & 66.6 & & 846.7 & 1415.4 \\
\hline
\end{tabular}

brown color, as showed by Hartley et al. (1999, 2000). They tested blue and brown colors with relative success at avoiding the consumption of poisoned grains by birds, suggesting such colors would cause aversion.

The notable ingestion of red seeds suggests that this color, attributed by rhodamine $\mathrm{B}$, is not aversive, rebutting Avery and Mason (1997) and Nelms and Avery (1997), but attractive (Schmidt et al., 2004; Cuthill et al., 2005). This color's spectral behavior, in the wavelengths visible by the birds, is similar to yellow and orange (Schmidt et al., 2004), which are contrasting and conspicuous and similar to beige. This may explain the high consumption of seeds treated with carbofuran without rhodamine B. Thus, independently of the reddish hue from rhodamine $\mathrm{B}$, or the beige color, coming from the syrup of carbofuran without rhodamine $\mathrm{B}$, there is a higher probability of birds detecting and ingesting less camouflaged seeds.

The camouflaging done only with powdered dye, despite the low operational and economic cost and its resistance to rain (Almeida, 2006), may have caused the poisoning of insectivorous birds, which did not happen with the liquid dye. Nevertheless, the coatings made with powder dyes and white glue resulted in camouflages that do not release powder so easily (Almeida, 2006).

The possibility of carbosulfan acting as a gustative repellent was not checked and, in addition, birds intoxicated by carbosulfan - vulnerable to predator attacks were able to reach shelters, like forest reserves. Effects of pesticides over the agricultural matrix may propagate through forest fragments, affecting negatively its quality and aggravating the problem of habitat fragmentation (Colli et al., 2005), one of the main causes of the biological diversity erosion (Harris, 1984; Harris and SilvaLopes, 1992).

These aspects are contrary to the use of carbosulfan and other products, which are up to 20 times less toxic than carbofuran, for the treatment of seeds or gustative repellents. In addition, evidences indicate that with animals, aversions and preferences for food items are often related to the taste and appearance of possible foods, but the poorly developed gustative sense of birds (Zuberbuehler et al., 2002) is a plausible reason for explaining limited results from Avery et al. (1998) and Moran (2001), using chemical repellents in the absence of alternative food sources. As seeds treated with pesti- cides must receive a different color to prevent accidents with humans, the camouflaging may be used for mitigating the mortality of birds in plantations, substituting rhodamine B.

High mortality rates confirmed for Brazil are consistent with warnings found in the literature (Eisler, 1985; Agriculture Canada, 1993; Mineau et al., 1999; Mineau, 2005) regarding the impact of carbofuran in wild birds. A warning issue by the Federal Government is in order, since the use of carbofuran and rhodamine B is conflicting with Brazilian Law $\mathrm{n}^{\circ} 7802$ from July, 11, 1989, which prohibits the registration of pesticides and components that may cause damage to the environment.

The population decrease of several bird species in agricultural areas in Europe and Canada has, as main suspect, the use of pesticides (McKay et al., 1999; Vickery et al., 2002; Mineau et al., 2005). In the light of the results coming from this study, research must be intensified to evaluate the magnitude of the impact of pesticides on the Brazilian wild fauna.

\section{Acknowledgements}

To Ana G. P. Campos, Cristiane de A. Amabilini, Sandra P. Cardoso, Mauricio Cetra, Pierre Mineau, Carlos A. Perez, Antonio N. Gonçalves and Antonio C. Zen. To the people who allowed studies in their properties: Waldemar Leal, Mauro Cândido de Souza Dias, Camilo Ruiz Marques and FMC Agricultural Products, for funding this research, as well as all the anonymous revisers.

\section{References}

Almeida, A. 2006. Camuflagem de sementes tratadas com agrotóxicos como medida mitigadora do impacto ambiental da intoxicação de aves silvestres em plantações de trigo, milho e arroz. Dr. Thesis. Universidade de São Paulo, Piracicaba, SP, Brazil. (in Portuguese with summary in English).

Avery, M.L. 2002. Avian reppelents. p.122-128. In: Plimer, J.R., ed. Encyclopedia of agrochemicals. John Wiley \& Sons, New York, NY, USA.

Avery, M.L.; Mason, J.R. 1997. Feeding responses of red-winged blackbirds to multisensory repellents. Crop Protection 16: 59 164.

Avery, M.L.; Humphery, J.S.; Primus, T.M.; Decker, D.G.; McGrane, A.P. 1998. Anthraquinone protects rice seed from birds. Crop Protection 17: 225-250. 
Begon, M.; Townsend, C.R.; Harper, J.L. 2006. Ecology: From individuals to ecosystems. Blackwell, Oxford, UK.

Agriculture Canada. 1993. Special Review of Carbofuran Inseticide: Effects on Avian Fauna and Value to Agriculture. Plant Industry Directorate, Ottawa, Canada.

Colli, G.R.; Accacio, G.M.; Antonini, Y.; Constantino, R.; franceschinelli, E.V.; Laps, R.R.; Scariot, A.; Vieira, M.V.; Wiederhecker, H.C. 2005; A fragmentação dos ecossistemas e a diversidade brasileira: uma síntese. p.318-324. In: Brasil. Ministério do Meio Ambiente. Fragmentação de ecossistemas: causas, efeitos sobre a diversidade e recomendações de políticas públicas. MMA/SBF, Brasília, DF, Brazil.

Cox, C. 1996. Pollution's legacy in our backyard. Journal of Pesticide Reform 16: 2-6.

Cuthill, I.; Steves, M.; Sheppard, J.; Maddocks, T.; Párraga, A.C.; Troscianko, T.S. 2005. Disruptive coloration and background pattern matching. Nature 434: 72-74.

Demattê, J.A.M.; Epiphanio, J.C.N.; Formaggio, 2003. A.R. Influência da matéria orgânica e de formas de ferro na reflectância de solos tropicais. Bragantia 62: 451-464.

Dolbeer, R.A. 1999. Overview and management of vertebrate pests. p.663-691.In: Ruberson, J.R., ed. Handbook of Vertebrate Pest Management. Marcel Dekker, NY, USA.

Eisler, R. 1985. Carbofuran hazards to fish, wildlife and invertebrates: a synoptic review. U.S. Fish and Wildlife Service Biological Report 85: 36.

Espig, S.A.; Reis, I.A.; Araújo, E.P.; Formaggio, A.R. 2005. Relação entre o fator de reflectância e teor de óxido de ferro em Latossolos brasileiros. Anais do Simpósio Brasileiro de Sensoriamento Remoto 12. INPE, Goiânia, GO, Brazil.

Frankel, K.; Sousa, S.; Cowan, R.; King, M. 2004. Concealment of the warfighter's equipment through enhanced polymer technology. 13-16 In: Proceedings of Army Science Conference 24. U.S. Army, Orlando, FL, USA.

Harris, L.D. 1984. The Fragmented Forest. University of Chicago Press, Chicago, IL, USA.

Harris, L.D.; Silva-Lopez, G. 1992. Forest fragmentation and the conservation of biological diversity. p.199-237. In: Fiedler, P.L.; Jain, S.K., eds. Conservation biology: the theory and practice of nature conservation, preservation and management. Chapman \& Hall, New York, NY, USA.

Hart, N.S. 2001. The visual ecology of avian photoreceptors. Progress in Retinal Eye Research 20: 675-703.

Hartley, L.; Waas, J.; O’Connor, C.; Matthews, L. 1999. Colour preferences and coloured bait consumption by weka Gallirallus australis, an endemic New Zealand rail. Biological Conservation 93: 255-263

Hartley, L.; O'Connor, C.; Waas, J.; Matthews, L. 2000. Colour preferences in North Island robins (Petroica australis): implications for deterring birds from poisonous baits. New Zealand Journal of Ecology 23: 255-259.

Hawthorne, D.W. 1987. Daños provocados por animales silvestres y técnicas de control. p.119-134. In: Schemnitz, S.D., ed. Manual de Técnicas de Gestión de Vida Silvestre. US Wildlife Society, Bethesda, MD, USA.
McKay, H.V.; Prosser, P.J.; Hart, A.D.M.; Langton, S.D.; Jones, A. McCoy, C.; Chandler-Morris, S.A.; Pascual, A. 1999. Woodpigeons avoid pesticide-treated cereal seed? Journal of Applied Ecology 36: 283-296.

Merilaita, S. 2003. Visual background complexity facilitates the evolution of camouflage. Evolution 57: 1248-1254.

Merilaita, S; Lind, J. 2005. Great tits (Parus major) searching for artificial prey: implications for cryptic coloration and symmetry. Behavioral Ecology 17: 84-87.

Mineau, P. 1993. The hazard of carbofuran to birds and other vertebrate wildlife. Technical Report Series. n.177, Environment Canada, Canadian Wildlife Service, Ottawa. XXii+96 pp.

Mineau, P.; Fletcher, M.R.; Glaser, L.C.; Thomas, N.J.; Brassard, C.; Wilson, L.K.; Elliott, J.E.; Lyon, L.A.; Henny, C.J.; Bolinger, T.; Porter, S.L. 1999. Poisoning of raptors with organophosphorus and carbamate pesticides with emphasis on Canada, U.S., and U.K. Journal of Raptor Research 33: 1-37.

Mineau, P. 2005. Direct Losses of Birds to Pesticides: Beginnings of a Quantification. USDA, Washington, D.C., USA. Forest Service General Technical Report PSW-GTR-191, 2, 1065-1070.

Moran, S. 2001. Aversion of the feral pigeon and the house sparrow to pellets as sprouts treated with commercial formulations of methyl anthranilate. Pest Management Science 57: 248-252.

Nelms, C.O.; Avery, M.L. 1997. Reducing bird repellent application rates by the additiion of sensory stimuli. International Journal of Pest Management 43: 187-190.

Pascual, J.A.; Hart, A.D.M.; Fryday, S.L. 1999. Incidence of lethal bird poisoning reduced by regurgitation of pesticide-treated food. Environmental Toxicology and Chemistry 18: 247-253.

Schmidt, V.; Schaefer, H.M.; Winkler, H. 2004. Conspicuousness, not colour as foraging cue in plant-animal signaling. Oikos 106: 551-557.

Sick, H. 1997. Ornitologia Brasileira. Nova Fronteira, Rio de Janeiro, RJ, Brazil.

Tobin, M.E. 2002. Developing methods to manage conflicts between humans and birds-three decades of change at the USDA National Wildlife Research Center. Proccedings of Vertebrate Pest Conference. University of California, Davis, CA, USA.

Vickery, J.A.; Carter, N.; Fuller, R.J. 2002. The potential value of managed cereal field margins as foraging habitats for farmland birds in the UK. Agriculture, Ecosystems and Environment 89: 41-52.

Zuberbuehler, C.A.; Messikommer, R.E.; Wenk, C. 2002. Choice feeding of selenium-deficient laying hens affects diet selection, selenium intake and body weight. Journal Nutritional 132: 34113417.

Zug, G.R.; Vitt, L.J.; Caldwell, J.P. 2001. Herpetology: An Introductory Biology of Amphibians and Reptiles. Academic Press, San Diego, CA, USA.

Received October 02, 2007

Accepted August 13, 2009 